\title{
Do We Have to Prohibit the Use of Mobile Phones in Classrooms?
}

\author{
http://dx.doi.org/10.3991/ijim.v9i2.4394 \\ H. Mohammad, A. Fayyoumi and O. AlShathry \\ Al Imam Mohammad Ibn Saud Islamic University (IMSIU), Riyadh, Saudi Arabia
}

\begin{abstract}
People take their mobile phones everywhere they go. In Saudi Arabia, the mobile penetration is very high and students use their phones for different reasons in the classroom. The use of mobile devices in classroom triggers an alert of the impact it might have on students' learning. This study investigates the association between the use of mobile phones during classroom and the learners' performance and satisfaction. Results showed that students get distracted, and that this diversion of their attention is reflected in their academic success. However, this is not applicable for all. Some students received high scores even though they declared using mobile phones in classroom, which triggers a request for a deeper study.
\end{abstract}

Index Terms-mobile phone in classroom, multitasking, impact on students learning, mobile phone actions in classroom.

\section{INTRODUCTION}

The relation between the advancements in digital technology and education on one hand, and economic strength of a nation on the other hand is undeniable. There has been a considerable proliferation of digital technologies over the past two decades. The number of personal computers in use worldwide surged from 100 million in 1990 to 1.4 billion by 2010 . In addition, there were 10 million mobile phone users in the world in 1990; today there are more than 5 billion [1]. Moreover, the number of Internet users grew at an even more rapid rate over the same decades, from 3 million to 2 billion [2].

Mobile services are increasingly dominating many aspects of our life worldwide. But will mobile phones replace the personal computers? It is hard to tell because of the advantages of computers with larger display and more powerful computing over the smaller devices. But what is obvious that technology is going mobile. Mobile users are increasing in number every day and the uses of mobile devices are almost interfering with most activities in our lives.

People take their mobile phones everywhere they go. They use it for different applications, such as in communication, social networking, entertainment, shopping, banking, and education. Besides, the surge in mobile phones use has not been restricted to the developed world. In Saudi Arabia, for example, internet penetration is $28 \%$, while the mobile penetration is $143 \%$ (number of mobile cellular subscriptions per 100 Inhabitants) as reported by the International Telecommunication Union (ITU) [3].

The majority of mobile phone users are among teenagers and students. In fact, the use of mobile phones has become accepted, even in classroom. Students are using their mobile phones during classroom for different rea- sons, viewing lecture slides for instance. However, they might use it for other activities such as social networking. Regardless what they are using it for, the use of mobile devices in classroom triggers an alert of the impact it might have on students' learning. This study investigates the association between the use of mobile phones during classroom and the learners' performance and satisfaction.

\section{Mobile PhONES AND EdUCATION}

With rapid development in information and communication technologies, educators and students are always seeking to reap the benefits of incorporating such advanced technologies in their teaching/learning activities, because technology dose impact learning [4]. However, the current growth in technology had been resulted in mobile technologies such as laptops and other mobile devices (Smartphones, PDA, and Tablets) which provide a wireless internet access beside many other features. These mobile technologies had been widely used in the academic environments and they move the learning process to another envision [5].

The 'digital natives' [6] have the needed skills to benefit and use mobile technologies, therefore, are more connected to technologies than their predecessors. They tend more to multitask, collaborate and network to carry out their daily as well as academic activities [7]. 'New millennium learners' [8], appreciate speed, innovation, multimedia and learning in more interactive approach. It had been estimated that $99.8 \%$ of higher education students have mobile phones, and $49 \%$ of those are smartphones.

In general, the wide use for mobile devices among university students is due to its characteristics and features. Mobile phones can act like mini notebook computer with an ability to provide internet connection. This capability to be online via wireless networks will provide mobile phones users with accessibility to information. They can search and retrieve information available on web easily at anytime and anywhere. Furthermore, mobile phones users can use many applications to use in different activities during their day, such as word processing and data management. Other characteristics that contribute to spread and intensive use of mobile phones is portability; mobile devices are designed to fit in your pocket with light weight. In addition, mobile devices are easy to use and learn. All these features on mobile phones students can enjoy it with reasonable cost $[9,10]$.

Researchers on [11] found that students who incorporate mobile devices in their learning activities are satisfying their expectations of getting the needed help to search and retrieve information from the internet. Furthermore, it had been proved that integrating mobile devices and tech- 
nology in the learning process will improve and enhance students learning attitudes as well as their accomplishments [12, 13]. On [14] studied the students' perceptions of using mobile phones in their classrooms and outside the classroom. They reported positive results on students' perceptions on using mobile phones in their classes. They highlighted that using mobile phones enable students to have quick access to course material, documents and discussions. Also, it's a good channel to communicate and interact with their classmate as well as with their instructors. The students reported that having mobile devices enable them to surf the course material and other external resource on the internet to enhance and enrich their class discussion. Students claim that they can find the needed information and materials 'just front of them' with no matter of time and effort.

However, contradicting view perspectives still arise regarding integrating and using mobile devices such as mobile phones, tablets and laptops in the classrooms. Despite, the reporting of positive effect of using the mobile computing technologies by many researchers $[14,13$, $\& 12]$. There are others who present the negative impact of using mobile devices in college classrooms $[15,16,17$, $18, \& 19]$. Recent study by [15] show that there is a negative impact for using mobile phones during the class on students' academic performance (GPA). They find that students who are using mobile phones in high frequencies are paying attention less to lectures and thus, their GPA is lower than students who are using mobile phones in lower frequencies. Also, they find that students with lower GPA having less satisfaction with life comparing to their colleagues who are using mobile phones less. Furthermore, [16] showed that using mobile phones, among first year students, for calling and texting has a negative impact on academic performance.

In Saudi Arabia, the mobile penetration is very high and students use their phones for different reasons in the classroom. With these contradicting results, the issue of allowing the use of mobile phones in university classes needs to be highlighted. This research investigates the impact of mobile phones on students' academic performance and satisfaction. This may give us an indication on wither to prohibit the use of mobile phones during class time or not.

\section{ReSEARCh Methodology}

The goal of this experiment is to study the association between the usage of mobile phones in classroom and the students' performance and satisfaction. In other words, this research intends to develop a model for identifying which students use their phones in classroom. For this study, a sample of 50 students at Al-Imam University has been surveyed. Participants were asked to evaluate the use of their mobile phones in classroom on scale from (1 never to 5- very often). Students' performance was measured in self-reported grade on scale from (1 - failed to 5 excellent). While students' satisfaction was measured by rating the extent to which the use of mobile phones let them feel toward the university $(1-$ not satisfied to $5-$ satisfied).

\section{RESULTS:}

The multiple regression analysis examined the relationship between academic performance and satisfaction of students from one side, and the use of mobile phones in the classroom. The correlation table reflects that less usage of mobile phones by students is correlated with academic performance and satisfaction of students as indicated by the level of significance of less than 0.05 ; that are 0.016 and 0.019 respectively. In addition to this, the results also reflect that the Pearson Correlation coefficients are in positive for academic performance and satisfaction of students that are 0.14 and 0.127 respectively. Keeping this in view, it can be said that less usage of mobile phones by students is positively correlated with academic performance and also satisfaction of students.

The model summary table of regression analysis is indicating that the value of $\mathrm{R}$ Square is 0.301 ; which indicates how much of the dependent variable (less usage of mobile phones), can be explained by the independent variables (academic performance and satisfaction of students). This also indicates that there seems to be association of dependent variable and the independent variables.

TABLE I.

CORRELATION TABLE

\begin{tabular}{|c|c|c|c|c|}
\hline \multicolumn{5}{|c|}{ Correlations } \\
\hline & & $\begin{array}{c}\text { Less } \\
\text { usage } \\
\text { of } \\
\text { mobile } \\
\text { phones }\end{array}$ & $\begin{array}{l}\text { Academic } \\
\text { Performance }\end{array}$ & $\begin{array}{l}\text { Satisfaction } \\
\text { of Students }\end{array}$ \\
\hline \multirow{3}{*}{$\begin{array}{l}\text { Pearson } \\
\text { Correlation }\end{array}$} & $\begin{array}{l}\text { Less usage } \\
\text { of mobile } \\
\text { phones }\end{array}$ & 1.000 & .140 & .127 \\
\hline & $\begin{array}{l}\text { Academic } \\
\text { Performance }\end{array}$ & - & 1.000 & .186 \\
\hline & $\begin{array}{l}\text { Satisfaction } \\
\text { of Students }\end{array}$ & - & - & 1.000 \\
\hline \multirow{3}{*}{$\begin{array}{l}\text { Sig. (1 - } \\
\text { tailed) }\end{array}$} & $\begin{array}{l}\text { Less usage } \\
\text { of mobile } \\
\text { phones }\end{array}$ & 1.000 & .016 & .019 \\
\hline & $\begin{array}{l}\text { Academic } \\
\text { Performance }\end{array}$ & - & 1.000 & .098 \\
\hline & $\begin{array}{l}\text { Satisfaction } \\
\text { of Students }\end{array}$ & - & - & 1.000 \\
\hline
\end{tabular}

TABLE II.

MODEL SUMMARY OF REgRESSION ANALYSIS

\begin{tabular}{|c|c|c|c|c|c|c|c|c|c|}
\hline \multicolumn{10}{|c|}{ Model Summary $^{\text {b }}$} \\
\hline \multirow[b]{2}{*}{ Model } & \multirow[b]{2}{*}{$\mathbf{R}$} & \multirow{2}{*}{$R^{2}$} & \multirow{2}{*}{$\begin{array}{c}\text { Adjust- } \\
\text { ed } \\
R^{2}\end{array}$} & \multirow[b]{2}{*}{$\begin{array}{l}\text { Std. Error of } \\
\text { the Estimate }\end{array}$} & \multicolumn{5}{|c|}{ Change Statistics } \\
\hline & & & & & $\begin{array}{c}R^{2} \\
\text { Change }\end{array}$ & F Change & df 1 & df 2 & Sig. F Change \\
\hline 1 & $.173^{\mathrm{a}}$ & .301 & .248 & 1.04008 & .030 & .729 & 2 & 47 & .048 \\
\hline \multicolumn{10}{|c|}{ a. Predictors: (Constant), Satisfaction of Students, Academic Performance } \\
\hline \multicolumn{10}{|c|}{ b. Dependent Variable: Less Usage of Mobile Phones } \\
\hline
\end{tabular}


The analysis of variance table is showing that the significance level is below 0.05 that is 0.048 ; thus, it reflects that the model applied can statistically significant in predicting the outcome variable.

The coefficients table is indicating that there is association of less usage of mobile phones by students with the academic performance and students' satisfaction. This statement can be endorsed by the level of significance, which is below 0.05 , that is 0.041 for academic performance and 0.047 for students' satisfaction. Besides, the multiple regression analysis also revealed that beta values of the independent variables, academic performance of students and satisfaction of students, are in positive, 0.116 and 0.102 respectively. Thus, as the usage of mobile phones by student's increases, the academic performance and the satisfaction of students decrease.

TABLE III.

VARIANCE ANALYSIS TABLE

\begin{tabular}{|c|c|c|c|c|c|c|}
\hline \multicolumn{7}{|c|}{ ANOVA $^{a}$} \\
\hline \multicolumn{2}{|r|}{ Model } & $\begin{array}{l}\text { Sum of } \\
\text { Squares }\end{array}$ & $\mathrm{df}$ & $\begin{array}{l}\text { Mean } \\
\text { Square }\end{array}$ & $\mathrm{F}$ & Sig. \\
\hline \multirow{3}{*}{1} & Regression & 1.577 & 2 & .788 & .729 & $.048^{\mathrm{b}}$ \\
\hline & Residual & 50.843 & 47 & 1.082 & & \\
\hline & Total & 52.420 & 49 & & & \\
\hline \multicolumn{7}{|c|}{ a. Dependent Variable: Less Usage of Mobile Phones } \\
\hline \multicolumn{7}{|c|}{$\begin{array}{l}\text { b. Predictors: (Constant), Satisfaction of Students, Academic Per- } \\
\text { formance }\end{array}$} \\
\hline
\end{tabular}

\section{Discussions And Future Research:}

Despite the research limitations, it can be concluded that students' performance and their satisfaction are significantly associated with less usage of mobile phones in the classroom. This indicates that less use of mobile phones during lecture time will help students in increasing their academic performance and also their level of satisfaction with respect to their academic studies. Keeping this in view, it can be said that students should be restricted to use the mobile phones in classroom; students' attention gets diverted due to games, social networking etc. which can be used on the mobile phones.

Research results agree with some researches that investigated the relationship between multitasking using laptops during lectures and students learning outcome [19]. His result shows a negative relationship to multiple learning outcomes such as course grade, understanding and clarity of lectures.

It is also critical that this diversion of students' attention reflected in their academic success. However, this is not applicable for all. Some students received high scores even though they declared using mobile phones, which triggers a request for a deeper study that differentiates those who used the mobile phones for lecture-related activities from those who did not.

Moreover, the students' performance data may have been influenced by subjective biases in self-report. It would be difficult to convince students to honestly answer the questionnaire while their identity is uncovered. In addition, students were from a single faculty and generalizability is low.

Future research in the area of mobile devices in university classrooms and their impact on performance of students should investigate the different uses and activities students perform during the lecture time. In fact, viewing a social networking site could have different impact than writing notes.

\section{REFERENCES}

[1] Morgan Stanley .The Mobile Internet Report. 2009. Internet: www.ms.com/techresearch. Accessed December 15, 2013.

[2] CITC (Communications and Information Technology Commission). 2010. Annual Report 2010. Internet: http://www.citc.gov.sa/English/MediaCenter/Annualreport/Docum ents/PR REP 006E.pdf. Accessed December 17, 2013.

[3] ITU's World Telecommunication/ICT Indicators and World dataBank World Development Indicators (WDI), Internet: http:// databank.worldbank.org. Accessed December 17, 2013.

[4] Tamim, R. M., et al. What forty years of research says about the impact of technology on learning: a second order meta-analysis and validation study. Review of Educational Research, (2011), 81(3): 4-28. http://dx.doi.org/10.3102/0034654310393361

[5] Wood, Eileen, et al. Examining the impact of off-task multitasking with technology on real-time classroom learning. Computers \& Education, ( 2012), 58(1):365-374. http://dx.doi.org/ 10.1016/j.compedu.2011.08.029

[6] Prensky, M. Digital natives, digital immigrants, Part 1. On the Horizon, (2001), 9(5): 1-6. http://dx.doi.org/10.1108/107481 20110424816

[7] Cotten, S. R., et al. (2011). Technological influences on social ties across the lifespan. In Karen Fingerman, Cynthia Berg, (eds Toni Antonucci, \& Jacqui Smith), Handbook of lifespan psychology (pp. 647-671). Springer Publishers.

[8] Pedro, F. (2006). The new Millennium Learners: Challenging our Views on ICT and Learning: OECD-CERI. Internet: http://www.oecd.org/dataoecd/1/1/38358359.pdf. Accessed December 18, 2013.

[9] Lenhart A, Ling R, Campbell S, Purcell K. Teens and mobile Phones. Pew Internet Web site. Internet: http://pewinternet.org/Reports/2010/Teens-and-Mobilephones.aspx. Accessed December 19, 2013.

[10] Lenhart A. Cell phones and American adults. Pew Internet Web site. Available at Internet: http://pewinternet.org/Repo rts/2010/Cell-Phones-and-American-Adults.aspx. Accessed December 19, 2013.

TABLE IV.

THE COEFFICIENTS TABLE

\begin{tabular}{|c|c|c|c|c|c|c|c|c|}
\hline \multicolumn{9}{|c|}{ Coefficients $^{\text {a }}$} \\
\hline & \multirow{2}{*}{ Model } & \multicolumn{2}{|c|}{ Unstandardized Coefficients } & \multirow{2}{*}{$\begin{array}{c}\begin{array}{c}\text { Standardized } \\
\text { Coefficients }\end{array} \\
\text { Beta } \\
\end{array}$} & \multirow[t]{2}{*}{$\mathrm{t}$} & \multirow{2}{*}{ Sig. } & \multicolumn{2}{|c|}{ Collinearity Statistics } \\
\hline & & $\mathrm{B}$ & Std. Error & & & & Tolerance & VIF \\
\hline \multirow{3}{*}{1} & (Constant) & 1.992 & .477 & & 4.176 & .000 & & \\
\hline & $\begin{array}{l}\text { Academic Perfor- } \\
\text { mance }\end{array}$ & .116 & .140 & .120 & .824 & .041 & .965 & 1.036 \\
\hline & $\begin{array}{l}\text { Satisfaction of Stu- } \\
\text { dents }\end{array}$ & .102 & .142 & .104 & .713 & .047 & .965 & 1.036 \\
\hline
\end{tabular}


[11] Tatar, D., et al. RHandhelds go to school: lessons learned. Computer, (2003). 36(9): 30-37. http://ieeexplore.ieee.org/stamp/ stamp.jsp?arnumber=01231192 $\underline{\text { http://dx.doi.org/10.1109/MC.20 }}$ 03.1231192

[12] Chu, H.-C., et al. A two-tier test approach to developing locationaware mobile learning systems for natural science courses. Computers \& Education, (2010), 55(4): 1618-1627. http://dx.doi.org/10.1016/j.compedu.2010.07.004

[13] Hwang, G.-J., \& Chang, H.-F. A formative assessment-based mobile learning approach to improving the learning attitudes and achievements of students. Computers \& Education, (2011), 56(1): 1023-1031. http://dx.doi.org/10.1016/j.compedu.2010.12.002

[14] Gikas, Joanne, et al. Mobile computing devices in higher education: Student perspectives on learning with cellphones, smartphones \& social media. Internet and Higher Education (2013), 19: 18-26. http://dx.doi.org/10.1016/j.iheduc.2013.06.002

[15] Lepp, Andrew, et al. The relationship between cell phone use, academic performance, anxiety, and Satisfaction with Life in college students. Computers in Human Behavior, (2014), 31: 343350. http://dx.doi.org/10.1016/j.chb.2013.10.049

[16] Jacobsen, et al. The wired generation: Academic and social outcomes of electronic media use among university students. $\mathrm{Cy}$ berpsychology, Behavior, and Social Networking, (2011), 14(5): 275-280. http://dx.doi.org/10.1089/cyber.2010.0135

[17] Junco, R., et al. Perceived academic effects of instant messaging use. Computers \& Education, (2011), 56: 370-378. http://dx.doi.org/10.1016/j.compedu.2010.08.020

[18] Junco, R., et al. No A 4 U: The relationship between multitasking and academic performance. Computers \& Education, (2012), 59, 505-514. http://dx.doi.org/10.1016/j.compedu.2011.12.023

[19] Fried, C. B. In-class laptop use and its effects on student learning. Computers \& Education. (2008), 50 (3): 906-914, http://dx.doi.org/10.1016/j.compedu.2006.09.006

[20] Smith, Shannon, et al. Study of undergraduate students and information technology research study. Boulder, CO: Educause center for applied research, (2010). Internet: http://www.educause.edu/Resources/ECARStudyofUndergraduate Studen/217333, Accessed December 21, 2013.

[21] Dahlstrom, Eden. ECAR study of undergraduate students and information technology. (2012). Louisville: CO: Educause Center for Applied $\quad$ Research
http://net.educause.edu/ir/library/pdf/ERS1208/ERS1208.pdf. Accessed December 21, 2013.

[22] Dobbin, Gregory. Educause Mobile Computing 5-Day Sprint: Day 2 recap - Teaching and learning. (2011). Internet: http://www.educause.edu/blog/gdobbin/MobileComputing5DaySp rintDay2R/227812. Accessed December 21, 2013.

\section{AUTHORS}

H. Mohammad is an Assistant Professor of Information Systems at the College of Computer and Information Sciences. Heba received her Ph.D in e-business from University of Salento, Italy. Her research focuses on knowledge management, e-Business \& e-learning and communities of practice. She also provides different consultation services to various institutions. (E-mail: hkmohammad@ccis.imamu.edu.sa).

A. Fayyoumi was an Assistant Professor of Information Systems at the College of Computer and Information Sciences. Ayham received his Ph.D in e-business from University of Salento, Italy. His research focuses on e-Learning, online exam systems, knowledge management, and e-Business. He also provides different consultation services to various institutions. He is currently working as a project Manager on PWC.(email:a.fayyoumi@gmail.com)

O. AlShathry, is an assistant professor at the information systems department at Imam Mohamed Bin Saud University in Riyadh. Omar received his Ph.D. in Software Engineering (Quality Assurance) from De Montfort University in 2010. His main research interests include software quality management and process improvement best practices (AlShathry@ccis.imamu.edu.sa).

Submitted 20 January 2015. Published as resubmitted by the authors 23 March 2015. 